体育学研究 $41: 82-93,1996$

\title{
スキー技術における構成要素の分析に関する研究： 運動項目及び操作項目を手がかりとして
}

\author{
森本信雄 ${ }^{1)}$ 国見保夫2) 山田信幸 ${ }^{2)}$ \\ 益田誠也 ${ }^{3)}$ 安達和 年4)
}

\section{Die Klassifikationsmethode in Bewegung und Lenkung für Skitechnik}

\author{
Morimoto Nobuo ${ }^{1}$, Kunimi Yasuo ${ }^{2}$, Yamada Nobuyuki², \\ Masuda Seiya ${ }^{3}$ and Adachi Kazutoshi ${ }^{4}$
}

\begin{abstract}
Im Laufe der Entwicklung des Skisports haben sich verschiedene Techniken als bewährt herausgestellt, für die eine Reihe praktischer Ubungen vorliegen. Der Zweck dieser Betrachtung besteht darin, daß die Hauptbestandteile der Skitechnik ins Klare gebracht werden sollen. Darum wurde der Versuch gemacht, die Techniken in Bewegungsfaktoren und Lenkungsfaktoren zu differenzieren. Es wird damit gezeigt, daß man durch Analyse der Technniken die Unterschiede in den einzelnen Ubungen logisch erklären kann, die Techniken ferner per Computer systematisch ordnen und so für den übersichtlichen Gebrauch zugänglich machen kann.
\end{abstract}

Key words: Ski, Technikschulung, Klassifikationsmethode in Bewegung und Lenkung (Japan J. Phys. Educ. 41: 82-93, July, 1996)

キーワード：スキー，技術指凅，通功操作分類法

\section{I．腥}

言

スキーは狩編用具, 雪上の交通手段として歴史 に登場し，さらにスポーツとして発達してきてい る。 またその技術は用具（靴，締め具，板など）, スキー場の整備（リフト，ゴンドラなど)，ゲレ ンデ状況（コフ，正雪など）の変化，アルペン競 技の進歩などにより形成発展してきたと考えられ $3^{11,15,16,25)}$ 。これらの発展過程において技術は難 易度で分類されることが多く14)，新しい技術が 出現すると，それを習得するための練習方法が開
発され，指導体系に付加されてきた経緙があ $ろ^{23)}$.

現在，学校で行われているスキ一教室などでス キ一指導を行う場合, SAJの日本スキー教程や 楽しいスキー教室など22,25,27)が示す指導法だけで 指導を行うことは難しい，それは，受講者の経験 や運動能力なとの個体差がある10,20)ことと，これ らの教程は各技術の完成型を難易度でまとめたも のであり，技術習得のための練習は基本例に過ぎ ないからであると考えられる，従って，指導者は 自らが指導を受けた時の経験を頼りに，受講者に 対する技術習得のためのバリエーションを選択 し，技術指導を行うことを余儀なくされている.
1) 玉川学園高等部

2) 玉川大学文学部

3）玉川大学工学部 干194 東京都町田市玉川学園 6-1-1

4）東京情報大学経営情報学部 于265 千葉県千葉市若葉区谷当町1200-2
1. Tamagawa gakuen, high school

2. Tamagawa University, Faculty of Letters

3. Tamagawa University, Faculty of Engineering, 6-1-1 Tamagawagakuen, Matida, Tokyo 194

4. Tokyo University of Information Sience, Faculty of Buisinss Administration and Information Sience, 1200-2 Yatoh-choh, Wakaba, Chibacity, Chiba 265 
福岡は「日本におけるスキ一技術は，種々雑多 な要素があたかもミックス・サラダのように未整 理のままで混然としている」としている，その原 因は外国からの導入にあたって，個々の技術を論 理的, 科学的に追求，分析せず客観的な要素を得 なかったこと，さらにそこから一般的な性質を見 い出して，知識を体系化することが欠けていたか らであると指摘している，福岡は，技術の体系化 を「バイオメカニックス手法」によって提案して いるが6), 本研究は運動学的立場9,13) からスキー 技術を論理的，客観的に分析，整理することを目 指している．また高村も「過去の教程にみられる ように，ただ種目の順序たての研究だけであって はならない，大切な一面には違いないが，斜滑 降, 横滑り…(中略) …パラレルクリスチャニア と列挙してみても，スキーそれ自体の運動として の根本原理と，それを体得してゆくときの学習者 との結びつきのうえにたって，教程が実際指尊の うえに具現されないかぎり，生きた取扱いのでき ないむのになってしまう.」と述へ，スキ一の運 動としての根本原理の重要性を強調している が24)，分析的な取扱い方法の確立には至ってい ない.

フランスのショルシュ・シュベールは「スキー 習得の本当の過程と呼ふすのを分析, 強調した い」とし，「テクニック要素」の考え方を提示し ている。これによると，1)バランス維持を可能 にする要素，2)フラットなスキー操作を可能に する要素，3)エッシングを使った滑りを可能に する要素, の3つにテクニック要妻を分類し， さらに「肉体とスキー用具の結び付き」「なだら かな斜面を滑りながらの前後のバランス」など細 分化を試みている4,5)，しかしこれもまだ分類の 途上であり，要素の数が非常に多く，全体が見え ないという久点を持っている.

筆者らは，スキ一技術を体系的に指導するため に，技術が各技術の構成要素群の総体であるこ と, 要素群の関連や発展によって技術レベルが成

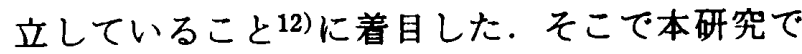
は，これら基本的な考え方に依拠しながら，スキ 一技術の構成要素を「運動項目」「操作項目」と
いう $2 つ の$ 視点で捉え,さらにスキーの位㯰関 係，運動のリズムを用いてスキー技術の分析，分 類を試みた。これにより，スキ一技術は主にこの 2 次元による明確な分析，分類が可能であること を明らかにし，さらに「バリエーション指導法」 の可能性を示すことを目的としている.

\section{II. 分 析 方 法}

スキーヤーはパラレルシュビンゲン（パラレル ターン)注1)の技術などにおいて，上体の前傾，回 転外側の入キーへの荷重, さらに外足から次の外 足への荷重の移動，スキ一の角付け，角付けを切 り替えること，角付けを切り替えるための立ち上 がり抜重, 遠心力に対して向心力を生むための内 傾姿势とバランスを保つための上体の外傾姿势, 回転の方向付けを行うためにスキ一の板を進行方 向へ捻ることなどを行っている.これらの現象は 構造的に次の例で解説することができる.

スキー技術を構成する要素の一つである「角付 け」は，滕を側方へ移動させることによりスキー のエッシと雪面との角度が大きくなる現象であ る.これまでこの現象は一般的に角付けの「操 作」,「運動」あるいは「技術」なとと呼ばれ，用 語として統一されていなかった，そこで，我々は スキー技術の分類上，混同注2)や間違いを避ける ために用語を以下のように定義する.

滕を側方へ移動させることは移動運動を伴うた め,これを「運動」と呼び，その運動の結果とし て起こるスキー自体の変化，つまりスキーと雪面 との関係が変化する現象を「操作」と呼ぶ.

以上のように定義した「運動」をさらにその方 向性によって分類した項目を「運動項目」(Bewegungsfaktoren)，をた「操作」を目的別に分 類した項目を「操作項目」(Lenkungsfaktoren)

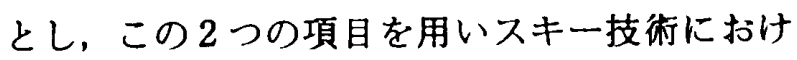
る構成要素の分析を試みた。

\section{1）分類項目}

\section{A. 運動項目}

運動項目は，重心移動運動と非重心移動運動の 2 つに大別できる.さらに，重心移動運動は，以 
下の 5 つの項目からなる.

(1) 上方運動（Aufwärtsbewegung）：低い姿 势から立ち上がる，伸び上がる，跳び上がる 運動

(2) 下方運動 (Abwärtsbewegung)：高い姿势 からしゃがむ，樎む，滕を抱え込む運動

(3) 前方運動（Vorwärtsbewegung）：重心が 前に移動する運動

(4) 後方運動（Rückwärtsbewegung）：重心が 後ろに移動する運動

(5) 側方運動（Seitwärtsbewegung）：重心が 左右に移動する運動

また，非重心移動運動には捻転運動（Verwindungsbewegung)，つまり「体軸に対して上半身 または下半身を捻る運動や脚部を内側及び外側に 捻る運動」が考えられ，これを項目とする。

但し，重心移動運動には，努維持運動として 視覚的に重心の移動の方向性が見られない運動も 含むむのとする.

B. 操作項目

操作項目はスキ一操作を目的別に整理したもの で以下の 5 項目からなる.

(1) 荷重操作 (Belastungslenkung)：スキー 板に負荷を加え滑らせる操作

(2) 拔重操作 (Entlastungslenkung)：スキー 板に加わっている負荷を除き，角付けを楥 め，または切り替えを行ないやすくする操作

(3) 姿势操作 (Haltungslenkung)：スキー板 に加わる負荷を維持する（姿势）操作

(4) 曲進操作 (Bogenlenkung)：スキ一を直 接的に曲進させる操作

(5) 回転操作 (Pendellenkung): スキーの曲 進運動を左右連続で行わせる操作

C. スキーの位䯓関係と運動のリズム

技術，練習バリエーションの違いを明確に区別 しょうとする時, 例えば「ペダルウェーデルンと 捻りウェーテルン」,「パラレルシュビンゲンとウ エーデルン」などにおいては運動項目と操作項目 たけでは充分な分類ができない，例えば「ペダル ウェーデルンと捻りウェーデルン」は共に脚の捻 りを強調した練習バリエーションであるが「ペダ
ルウェーデルン」はスキーの位固関俰 ${ }^{18)}$ がブル 一クから平行へと変化し、「捻りのウェーデルン」 は平行のままである。 また、「パラレルシュビン ゲンとウェーデルン」も運動と操作は同じである が、「バラレルシュビンゲン」はリズムの遅い回 転技術であり，「ウェーデルン」は速い回転技術 である．そこで本稿では分類項目として，さらに 「スキーの位膡関係」(Skistellung) と「運動の リズム」(Bewegungsrhythmus) を付加して考 える.

スキ一の位睓関係は「ブルーク」「平行」「シェ ーレ」「混合」を，また運動のリズムは「速い」「普 通」「痋い」「混合」を要素とする.

\section{2）分析表の提示}

上述した $2 つ の$ 項目と, さらにスキーの位膡 関係，運動のリズムによってスキー技術の分析を 試みた，Tabelle 1 は横軸に運動項目，縦軸に操 作項目，さらにスキーの位睆関係と運動のリズム を配置した「運動・操作による技術構成要素分析 表」（以後分析表と呼ふ）である．各項目が重な る欄は技術構成要素を具体的に表しており，技術 構成要素は各運動・操作の現象を示している.

スキ一技術の構造は構成要素が複合して構成要 妻群となり，さらにそれらの構成要素群の集合し たものが技術となると考えられる。したがって， 各技術や練習バリエーション注3ははこの構成要素 の組み合わせで表現することができ，分類が可能 になると思われる。

大筑は「その動きを構成する要素的動きの数が 多いほど，その動きは複雑であると表現され る」17）としているように，この分析表です高度 な技術，練習バリエーションほど多くの構成要素 を持つ結果となっている，筆者らはこの分析表を 用いて技術を分類する方法を「運動・操作分類法」 と名付けた。

\section{III. 結果及び考璂}

\section{1）技術構成要案による分析}

スキー技術をオーストリア教程や日本スキー教 程など2,3,7,19,21,25) に基ついて具体的に以下の項目 
Tabelle 1 Klassifikation nach Bewegungs- und Lenkungsfaktoren

\begin{tabular}{|c|c|c|c|c|c|c|c|}
\hline & & \multicolumn{6}{|c|}{ Bewegungsfaktoren } \\
\hline & & \multicolumn{5}{|c|}{ Bewegung mit Verlagerung des Körperschwerpunkts (KSP) } & \multirow{2}{*}{\begin{tabular}{|c|}
$\begin{array}{c}\text { Bewegung ohne } \\
\text { Verlagerung } \\
\text { des KSP }\end{array}$ \\
$\begin{array}{c}\text { Verwindungs- } \\
\text { bewegung }\end{array}$ \\
\end{tabular}} \\
\hline & & $\begin{array}{l}\text { Aufwärts- } \\
\text { bewegung }\end{array}$ & $\begin{array}{l}\text { Abwärts- } \\
\text { bewegung }\end{array}$ & $\begin{array}{l}\text { Vorwärts- } \\
\text { bewegung }\end{array}$ & $\begin{array}{l}\text { Rückwärts- } \\
\text { bewegung }\end{array}$ & Seitwärtsbewegung & \\
\hline \multirow{5}{*}{$\begin{array}{l}\text { Lenkungs- } \\
\text { faktoren }\end{array}$} & $\begin{array}{l}\text { Belastungs- } \\
\text { lenkung }\end{array}$ & $\begin{array}{l}\text { Hoch- } \\
\text { belastung }\end{array}$ & $\begin{array}{l}\text { Tief- } \\
\text { belastung } \\
\text { Mittelb }\end{array}$ & $\begin{array}{l}\text { Vorwärts- } \\
\text { belastung } \\
\text { elastung }\end{array}$ & $\begin{array}{l}\text { Rückwärts- } \\
\text { belastung }\end{array}$ & $\begin{array}{l}\text { Seitwärtsbelastung } \\
\text { Talfußbelastung } \\
\text { Bergfußbelastung } \\
\text { Außenfußbelastung } \\
\text { Innenfußbelastung }\end{array}$ & \\
\hline & $\begin{array}{l}\text { Entlastungs- } \\
\text { lenkung }\end{array}$ & $\begin{array}{l}\text { Hoch- } \\
\text { entlastung }\end{array}$ & $\begin{array}{l}\text { Tief- } \\
\text { entlastung }\end{array}$ & $\begin{array}{l}\text { Vor- } \\
\text { Rückwärts- } \\
\text { entlastung }\end{array}$ & $\begin{array}{l}\text { Rück- } \\
\text { Vorwärts- } \\
\text { entlastung }\end{array}$ & $\begin{array}{l}\text { Wechselseit- } \\
\text { entlastung }\end{array}$ & \\
\hline & $\begin{array}{l}\text { Haltungs- } \\
\text { lenkung }\end{array}$ & Hochlage & $\begin{array}{l}\text { Tieflage } \\
\text { Mitt }\end{array}$ & $\begin{array}{l}\text { Vorlage } \\
\text { ellage }\end{array}$ & Rücklage & \multirow{2}{*}{\multicolumn{2}{|c|}{\begin{tabular}{l|l}
\multicolumn{2}{c}{ Knicklage } \\
Innenlage \\
Kanteneinsatz & Anrotieren \\
Schieben & Beinedrehen \\
Beidseitsfersenschub \\
Einseitsfersenschub
\end{tabular}}} \\
\hline & $\begin{array}{l}\text { Bogen- } \\
\text { lenkung }\end{array}$ & & & & & & \\
\hline & $\begin{array}{l}\text { Pendel- } \\
\text { lenkung }\end{array}$ & & & & & $\begin{array}{l}\text { Belastungswechsel } \\
\text { Umkanten }\end{array}$ & Antizipation \\
\hline \multicolumn{2}{|c|}{ Skistellung } & Parallel, & Pflug, & Schere, & \multicolumn{3}{|l|}{ Gemisch. } \\
\hline \multicolumn{2}{|c|}{ Bewegungsrhythmus } & Lang, & Kurz, & Ohne, & \multicolumn{3}{|l|}{ Gemisch. } \\
\hline \multicolumn{2}{|c|}{ Technikskategorie } & \multicolumn{6}{|c|}{$\begin{array}{l}\text { Schußfahren, Pflugfahren, Pflugbogen, Schrägfahren, Seitrutschen, } \\
\text { Schwingen zum Hang, Stemmschwingen, Parallelschwingen, Wedeln, Scherschwingen. }\end{array}$} \\
\hline
\end{tabular}

について分析を行った.

(1) 直滑降 : 基本努势である「中間荷重 (Mittelbelastung)」「中間姿势（Mittellage）」で 斜面のフォールライン上を滑降する技術.

(2) ブルークファーレン: 捻り押し出し \{角付 け (Kanteneinsatz)，押し出し(Schieben)， 脚の捻り（Beinedrehen）を同時に行う\}を 左右両側へ同時に行う両側捻り押し出し (Beidseitsfersenschub) によりスピードを コントロールしながらフォールライン上を滑 降する技術.

フルルークの作り方には脚を曲げながらの曲 げブルークや伸ばしながらの伸ばしブルーク などがある。ここでは完成型である中間荷 重, 中間努でのプルークファーレンを扱 j.

(3) ブルークボーケン:ブルークファーレンで
行われた両側捻り押し出しを片側つつ交互に 強く行う技術.

適度な外向姿势 (Gegendrehen）と外傾 努势（Außenlage）を同時に行う外向㑯姿勢 （Knicklage）を作り外足荷重することでさ らに明確な曲進運動が起こり，荷重交換 (Belastungswechsel) を左右交互に行うこ とで回転運動となる．曲げブルークや伸ばし ブルークなとでは，伸身抜重 (Hochentlastung）や屈身抜重（Tiefentlastung）な とが行われる。ここでは意識的に明確な抜重 操作を行わない交互抜重（Wechselseitentlastung）の完成型ブルークボーゲンを扱 う.

(4) 斜滑降: 斜面を横切る際, 中間荷重, 中間 努势を行い, スキーがフォールライン方向に ずれ落ちないように角付けを行う技術. 
その際，バランスを保ち確実な角付けを行 うために谷側荷重（Talfußbelastung），外向 傾姿勢をとる。

(5) 横滑り：斜滑降でのスピードを横ずれでコ ントロールするために角付けを䜌める操作を 行い，雪面からの抵抗に耐えるために押し出 しや脚の捻り操作を行う技術。

角付けを綬めるきっかけとして伸身抜重な どを行う場合もあるがここでは完成型の横滑 りを扱う。

(6) 山側へのシュビンゲン：中間荷重と谷足荷 重，中間姿势と外向傾姿勢，捻り押し出しを 行い曲がる技術.

技術の発展段階では明らかに抜重操作を行 うが，ここでは完成型の山側へのシュビンゲ ンを扱う。スキーの位圈関係は混合となる が，初歩の段階では開き出しの大きなプルー クであり，技術の発展にともない平行のまま となる。

（7) シュテムシュビンゲン：中間荷重と外足荷 重, 中間姿势と外向傾姿势, 片側捻り押し出 し（Einseitsfersenschub）を行い，交互报 重と荷重交換に加えて角付けの切り替え （Umkanten）を外足，内足交互に行うこと により曲がる技術.

スキ一の開き出しの大きさと荷重移動のタ イミングに段階的な差があるが，スキ一の位 㯰関係は混合である。

(8) パラレルシュビンゲン：中間荷重と外足荷 重, 中間姿勢と外向傾姿勢, 片側捻り押し出 し，交互抜重と荷重交换を行い，さらに角付 けの切り替えを両足同時に行う技術. スキー の位置関俰は平行で遅い運動リスムによりス ムーズな回転を行う。

(9) ウェーデルン：構成要素は分類上ではパラ レルシュビンゲンと同じであるが, 違いは運 動リズムが速いことである．しかし，外向の 姿勢がより強くなり，それが先行動作（Antizipation）となる技術.

(10) シェーレシュビンゲン：スキーをシェーレ に開き出すことと, 回転の中期から後期にか
けて内足荷重 (Innenfußbelastung)，内傾姿 势 (Innenlage)，ふりこみ (Anrotieren) を とる技術。

運動リズムは混合である.

\section{2）抽出表示による分類と考察}

Tabelle 2 は「ウェーデルン」について各構成 要妻を抽出したものを示している. 運動項目の上 下, 前後運動と操作項目の荷重操作が重なる要素 は「中間荷重」となり，側方運動は「外足荷重」 となる．これはスキーヤーの意識，行動として中 間荷重でさらに外足荷重を行うことを示してい る. 同様に抜重, 姿势, 曲進, 回転の各操作で交 互抜重, 中間姿势, 外向姿勢, 片側捻り押し出 し，角付け切り替え，先行動作が行われる.

これらのパターンは，技術ごとに分析表上異な る表示がなされることになる，したがって，個々 の技術の外見からみられる相違だけでなく，技術 を構成する要素の相違を示すことができ，明確な 分類ができるようになっている．また，個々の技 術間の共通構成要素を確認することができ，各技 術の関連性や発展性を認識することができる。こ のことにより，体系的，発展的に指導の基礎を認 識することができると考えられる.

\section{3）運動・操作分類法を用いた練習バリエーショ ンの理解}

各技術には多様な練習バリエーションがある。

Tabelle 2 Wedeln

\begin{tabular}{l|l|l|l}
\hline & $\begin{array}{c}\text { Auf-, Ab-, Vor-, } \\
\text { Rückwärts- } \\
\text { bewegung }\end{array}$ & Seitwärtsbewegung & $\begin{array}{l}\text { Verwindungs- } \\
\text { bewegung }\end{array}$ \\
\hline $\begin{array}{l}\text { Belastungs- } \\
\text { lenkung }\end{array}$ & Mittelbelastung & Außenfußbelastung & \\
\hline $\begin{array}{l}\text { Entlastungs- } \\
\text { lenkung }\end{array}$ & & $\begin{array}{l}\text { Wechselseit- } \\
\text { entlastung }\end{array}$ & \\
\hline $\begin{array}{l}\text { Haltungs- } \\
\text { lenkung }\end{array}$ & Mittellage & & Gegendrehen \\
\hline $\begin{array}{l}\text { Bogen- } \\
\text { lenkung }\end{array}$ & & \multicolumn{2}{|c}{ Einseitsfersenschub } \\
\hline $\begin{array}{l}\text { Pendel- } \\
\text { lenkung }\end{array}$ & & $\begin{array}{l}\text { Belastungswechsel } \\
\text { Umkanten }\end{array}$ & Antizipation \\
\hline
\end{tabular}


Tabelle 3 Klassifikation für Ưbungsreihe (Pflugfahren-Fersenschübe)

\begin{tabular}{|c|c|c|c|c|c|c|c|}
\hline \multicolumn{2}{|c|}{$\begin{array}{l}\text { Bewegungsfaktoren } \\
\text { Lenkungsfaktoren }\end{array}$} & $\begin{array}{l}\text { Aufwärts- } \\
\text { bewegung }\end{array}$ & $\begin{array}{l}\text { Abwärts- } \\
\text { bewegung }\end{array}$ & $\begin{array}{l}\text { Vorwärts- } \\
\text { bewegung }\end{array}$ & $\begin{array}{l}\text { Rückwärts- } \\
\text { bewegung }\end{array}$ & $\begin{array}{l}\text { Seitwärts- } \\
\text { bewegung }\end{array}$ & $\begin{array}{l}\text { Verwindungs- } \\
\text { bewegung }\end{array}$ \\
\hline \multirow{10}{*}{$\begin{array}{l}\text { Belastungs- } \\
\text { lenkung }\end{array}$} & Hochbelastung & & & & & & \\
\hline & Tiefbelastung & & & & & & \\
\hline & Vorwärtsbelastung & & & & & & \\
\hline & Rückwärtsbelastung & & & & & & \\
\hline & Mittelbelastung & 0 & $\mathrm{O}$ & 0 & $\mathrm{O}$ & & \\
\hline & Seitwärtsbelastung & & & & & & \\
\hline & Talfußbelastung & & & & & & \\
\hline & Bergfußbelastung & & & & & & \\
\hline & Außenfußbelastung & & & & & & \\
\hline & Innenfußbelastung & & & & & & \\
\hline \multirow{5}{*}{$\begin{array}{l}\text { Entlastungs- } \\
\text { lenkung }\end{array}$} & Hochentlastung & & & & & & \\
\hline & Tiefentlastung & & & & & & \\
\hline & Vor-Rückwärtsentlastung & & & & & & \\
\hline & Ruck-Vorwärtsentlastung & & & & & & \\
\hline & Wechselseitentlastung & & & & & & \\
\hline \multirow{9}{*}{$\begin{array}{l}\text { Haltungs- } \\
\text { lenkung }\end{array}$} & Hochlage & & & & & & \\
\hline & Tieflage & & & & & & \\
\hline & Vorlage & & & & & & \\
\hline & Rücklage & & & & & & \\
\hline & Mittellage & $\bullet$ & - & $\bullet$ & - & & \\
\hline & Innenlage & & & & & & \\
\hline & Außenlage & & & & & & \\
\hline & Gegendrehen & & & & & & \\
\hline & Knicklage & & & & & & \\
\hline \multirow{6}{*}{$\begin{array}{l}\text { Bogen- } \\
\text { lenkung }\end{array}$} & Kanteneinsatz & & & & & $\cdot$ & \\
\hline & Schieben & & & & & - & \\
\hline & Anrotieren & & & & & & \\
\hline & Beinedrehen & & & & & & $\bullet$ \\
\hline & Beidseitsfersenschub & & & & & 0 & 0 \\
\hline & Einseitsfersenschub & & & & & & \\
\hline \multirow{3}{*}{$\begin{array}{l}\text { Pendel- } \\
\text { lenkung }\end{array}$} & Belastungswechsel & & & & & & \\
\hline & Umkanten & & & & & & \\
\hline & Antizipation & & & & & & \\
\hline
\end{tabular}


これらを運動・操作分類法を用い，系統立てて整 理することを試みた。

Tabelle 3 は, Tabelle 1 の分析表の操作項目を 各構成要素ことに展開して，2 次元に配置したも のである.ここではプルークファーレンの練習バ リエーションである「連続押し出し」の各構成要
素を示している．ここでの各要素は，それぞれの 練習背景や主たる練習目的を明確にするために， 既習得構成要素を「・」で，練習の主目的構成要 素を「○」で表している. Tabelle 4 は， Tabelle 3 の「・」や「○」の印のない操作項目 を省略して，技術名，課題名，スキーの位置関

Tabelle 4 Klassifikation für UUbungsreihe (Pflugfahren-Fersenschübe)

\begin{tabular}{|c|c|c|c|c|c|c|c|c|}
\hline \multicolumn{2}{|c|}{ Technikkategorie } & \multicolumn{7}{|l|}{ Pflugfahren } \\
\hline \multicolumn{2}{|c|}{ Ubungsname } & \multicolumn{7}{|l|}{ Fersenschübe } \\
\hline \multicolumn{3}{|c|}{ Lenkungsfaktoren } & $\begin{array}{l}\text { Aufwärts- } \\
\text { bewegung }\end{array}$ & $\begin{array}{c}\text { Abwärts- } \\
\text { bewegung }\end{array}$ & $\begin{array}{l}\text { Vorwärts- } \\
\text { bewegung }\end{array}$ & $\begin{array}{c}\text { Rückwärts- } \\
\text { bewegung }\end{array}$ & $\begin{array}{l}\text { Seitwärts- } \\
\text { bewegung }\end{array}$ & $\begin{array}{c}\text { Verwindungs- } \\
\text { bewegung }\end{array}$ \\
\hline $\begin{array}{l}\text { Belastungs- } \\
\text { lenkung }\end{array}$ & \multicolumn{2}{|c|}{ Mittelbelastung } & 0 & 0 & 0 & 0 & & \\
\hline $\begin{array}{l}\text { Haltungs- } \\
\text { lenkung }\end{array}$ & \multicolumn{2}{|c|}{ Mittellage } & • & & $\bullet$ & $\bullet$ & & \\
\hline \multirow{4}{*}{$\begin{array}{l}\text { Bogen- } \\
\text { lenkung }\end{array}$} & \multicolumn{2}{|c|}{ Kanteneinsatz } & & & & & - & \\
\hline & \multicolumn{2}{|l|}{ Schieben } & & & & & $\bullet$ & \\
\hline & \multicolumn{2}{|c|}{ Beinedrehen } & & & & & & $\bullet$ \\
\hline & \multicolumn{2}{|c|}{ Beidseitsfersenschub } & & & & & 0 & 0 \\
\hline \multicolumn{2}{|l|}{ Skistellung } & \multicolumn{7}{|l|}{ Gemisch } \\
\hline \multicolumn{2}{|c|}{ Bewegungsrhythmus } & \multicolumn{7}{|l|}{ Kurz } \\
\hline
\end{tabular}

Tabelle 5 Klassifikation für Ubungsreihe (Pflugfahren-Große und kleine Pflüge)

\begin{tabular}{|c|c|c|c|c|c|c|c|c|}
\hline \multicolumn{2}{|c|}{ Technikkategorie } & \multicolumn{7}{|l|}{ Pflugfahren } \\
\hline \multicolumn{2}{|c|}{ Übungsname } & \multicolumn{7}{|c|}{ Große und kleine Pflüge } \\
\hline \multicolumn{3}{|c|}{ Lenkungsfaktoren } & $\begin{array}{l}\text { Aufwärts- } \\
\text { bewegung }\end{array}$ & $\begin{array}{c}\text { Abwärts- } \\
\text { bewegung }\end{array}$ & $\begin{array}{l}\text { Vorwärts- } \\
\text { bewegung }\end{array}$ & $\begin{array}{l}\text { Rückwärts- } \\
\text { bewegung }\end{array}$ & $\begin{array}{l}\text { Seitwärts- } \\
\text { bewegung }\end{array}$ & $\begin{array}{l}\text { Verwindungs- } \\
\text { bewegung }\end{array}$ \\
\hline $\begin{array}{l}\text { Belastungs- } \\
\text { lenkung }\end{array}$ & \multicolumn{2}{|c|}{ Mittelbelastung } & 0 & 0 & 0 & 0 & & \\
\hline $\begin{array}{l}\text { Haltungs- } \\
\text { lenkung }\end{array}$ & \multicolumn{2}{|c|}{ Mittellage } & • & • & - & - & & \\
\hline \multirow{4}{*}{$\begin{array}{l}\text { Bogen- } \\
\text { lenkung }\end{array}$} & \multicolumn{2}{|c|}{ Kanteneinsatz } & & & & & $\bullet$ & \\
\hline & \multicolumn{2}{|l|}{ Schieben } & & & & & $\bullet$ & \\
\hline & \multicolumn{2}{|c|}{ Beinedrehen } & & & & & & - \\
\hline & \multicolumn{2}{|c|}{ Beidseitsfersenschub } & & & & & 0 & 0 \\
\hline \multicolumn{2}{|l|}{ Skistellung } & \multicolumn{7}{|l|}{ Pflug } \\
\hline \multicolumn{2}{|c|}{ Bewegungsrhythmus } & \multicolumn{7}{|l|}{ Lang } \\
\hline
\end{tabular}


Tabelle 6 Klassifikation für Übungsreihe (Wedeln-Pflugwedeln)

\begin{tabular}{|c|c|c|c|c|c|c|c|c|}
\hline \multicolumn{2}{|c|}{ Technikkategorie } & \multicolumn{7}{|l|}{ Wedeln } \\
\hline \multicolumn{2}{|c|}{ Übungsname } & \multicolumn{7}{|l|}{ Pflugwedeln } \\
\hline \multicolumn{3}{|c|}{$\begin{array}{l}\text { Bewegungsfaktoren } \\
\text { Lenkungsfaktoren }\end{array}$} & $\begin{array}{l}\text { Aufwärts- } \\
\text { bewegung }\end{array}$ & $\begin{array}{l}\text { Abwärts- } \\
\text { bewegung }\end{array}$ & $\begin{array}{l}\text { Vorwärts- } \\
\text { bewegung }\end{array}$ & $\begin{array}{l}\text { Rückwärts- } \\
\text { bewegung }\end{array}$ & $\begin{array}{l}\text { Seitwärts- } \\
\text { bewegung }\end{array}$ & $\begin{array}{l}\text { Verwindungs- } \\
\text { bewegung }\end{array}$ \\
\hline \multirow{2}{*}{$\begin{array}{l}\text { Belastungs- } \\
\text { lenkung }\end{array}$} & \multicolumn{2}{|c|}{ Mittelbelastung } & -.. & $\cdot$ & -. & $\bullet$ & & \\
\hline & \multicolumn{2}{|c|}{ Außenfußbelastung } & & & & & - & \\
\hline \multirow{2}{*}{$\begin{array}{l}\text { Haltungs- } \\
\text { lenkung }\end{array}$} & \multicolumn{2}{|c|}{ Mittellage } & -. & - & 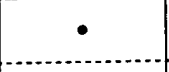 & $\bullet$ & & \\
\hline & \multicolumn{2}{|c|}{ Gegendrehen } & & & & & & $\bullet$ \\
\hline \multirow{4}{*}{$\begin{array}{l}\text { Bogen- } \\
\text { lenkung }\end{array}$} & \multicolumn{2}{|c|}{ Kanteneinsatz } & & & & & & \\
\hline & \multicolumn{2}{|l|}{ Schieben } & & & & & & \\
\hline & \multicolumn{2}{|c|}{ Beinedrehen } & & & & & & \\
\hline & \multicolumn{2}{|c|}{ Einseitsfersenschub } & & & & & $\bullet$ & $\bullet$ \\
\hline \multirow{3}{*}{$\begin{array}{l}\text { Pendel- } \\
\text { lenkung }\end{array}$} & \multicolumn{2}{|c|}{ Belastungswechsel } & & & & & 0 & \\
\hline & \multicolumn{2}{|c|}{ Umkanten } & & & & & & \\
\hline & \multicolumn{2}{|c|}{ Antizipation } & & & & & & \\
\hline \multicolumn{2}{|l|}{ Skistellung } & \multicolumn{7}{|l|}{ Pflug } \\
\hline \multicolumn{2}{|c|}{ Bewegungsrhythmus } & \multicolumn{7}{|l|}{ Kurz } \\
\hline
\end{tabular}

Tabelle 7 Klassifikation für Übungsreihe (Wedeln-Umsteigwedeln)

\begin{tabular}{|c|c|c|c|c|c|c|c|c|}
\hline \multicolumn{2}{|c|}{ Technikkategorie } & \multicolumn{7}{|l|}{ Wedeln } \\
\hline \multicolumn{2}{|l|}{ Übungsname } & \multicolumn{7}{|c|}{ Umsteigwedeln } \\
\hline \multicolumn{3}{|c|}{$\begin{array}{l}\text { Bewegungsfaktoren } \\
\text { Lenkungsfaktoren }\end{array}$} & $\begin{array}{l}\text { Aufwärts- } \\
\text { bewegung }\end{array}$ & $\begin{array}{c}\text { Abwärts- } \\
\text { bewegung }\end{array}$ & $\begin{array}{l}\text { Vorwärts- } \\
\text { bewegung }\end{array}$ & $\begin{array}{c}\text { Rückwärts- } \\
\text { bewegung }\end{array}$ & $\begin{array}{l}\text { Seitwärts- } \\
\text { bewegung }\end{array}$ & $\begin{array}{l}\text { Verwindungs- } \\
\text { bewegung }\end{array}$ \\
\hline \multirow{2}{*}{$\begin{array}{l}\text { Belastungs- } \\
\text { lenkung }\end{array}$} & \multicolumn{2}{|c|}{ Mittelbelastung } & -... & - & - & $\bullet$ & & \\
\hline & \multicolumn{2}{|c|}{ Außenfußbelastung } & & & & & $\bullet$ & \\
\hline $\begin{array}{l}\text { Entlastungs- } \\
\text { lenkung }\end{array}$ & \multicolumn{2}{|c|}{ Wechselseitentlastung } & & & & & 0 & \\
\hline \multirow{2}{*}{$\begin{array}{l}\text { Haltungs- } \\
\text { lenkung }\end{array}$} & \multicolumn{2}{|l|}{ Mittellage } & - & - & -.. & - & & \\
\hline & \multicolumn{2}{|c|}{ Gegendrehen } & & & & & & $\bullet$ \\
\hline \multirow{4}{*}{$\begin{array}{l}\text { Bogen- } \\
\text { lenkung }\end{array}$} & \multicolumn{2}{|c|}{ Kanteneinsatz } & & & & & & \\
\hline & \multicolumn{2}{|l|}{ Schieben } & & & & & & \\
\hline & \multicolumn{2}{|c|}{ Beinedrehen } & & & & & & \\
\hline & \multicolumn{2}{|c|}{ Einseitsfersenschub } & & & & & $\bullet$ & $\bullet$ \\
\hline \multirow{3}{*}{$\begin{array}{l}\text { Pendel- } \\
\text { lenkung }\end{array}$} & \multicolumn{2}{|c|}{ Belastungswechsel } & & & & & 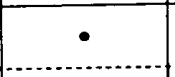 & \\
\hline & \multicolumn{2}{|c|}{ Umkanten } & & & & & $\cdot$ & \\
\hline & \multicolumn{2}{|c|}{ Antizipation } & & & & & & \\
\hline \multicolumn{2}{|l|}{ Skistellung } & \multicolumn{7}{|l|}{ Schere } \\
\hline \multicolumn{2}{|c|}{ Bewegungsrhythmus } & \multicolumn{7}{|l|}{ Kurz } \\
\hline
\end{tabular}


Tabelle 8 Klassifikation für Übungsreihe (Wedeln-Pedalwedeln)

\begin{tabular}{|c|c|c|c|c|c|c|c|c|}
\hline \multicolumn{2}{|c|}{ Technikkategorie } & \multicolumn{7}{|l|}{ Wedeln } \\
\hline \multicolumn{2}{|l|}{ U̇bungsname } & \multicolumn{7}{|l|}{ Pedalwedeln } \\
\hline \multicolumn{3}{|c|}{ Lenkungsfaktoren } & $\begin{array}{l}\text { Aufwärts- } \\
\text { bewegung }\end{array}$ & $\begin{array}{c}\text { Abwärts- } \\
\text { bewegung }\end{array}$ & $\begin{array}{l}\text { Vorwärts- } \\
\text { bewegung }\end{array}$ & $\begin{array}{l}\text { Rückwärts- } \\
\text { bewegung }\end{array}$ & $\begin{array}{l}\text { Seitwärts- } \\
\text { bewegung }\end{array}$ & $\begin{array}{l}\text { Verwindungs- } \\
\text { bewegung }\end{array}$ \\
\hline \multirow{2}{*}{$\begin{array}{l}\text { Belastungs- } \\
\text { lenkung }\end{array}$} & \multicolumn{2}{|c|}{ Mittelbelastung } & $\bullet$ & - & $\cdot$ & $\bullet$ & & \\
\hline & \multicolumn{2}{|c|}{ Außenfußbelastung } & & & & & $\bullet$ & \\
\hline $\begin{array}{l}\text { Entlastungs- } \\
\text { lenkung }\end{array}$ & \multicolumn{2}{|c|}{ Wechselseitentlastung } & & & & & 0 & \\
\hline \multirow{2}{*}{$\begin{array}{l}\text { Haltungs- } \\
\text { lenkung }\end{array}$} & \multicolumn{2}{|c|}{ Mittellage } & - & - & $\cdot$ & - & & \\
\hline & \multicolumn{2}{|c|}{ Gegendrehen } & & & & & & $\bullet$ \\
\hline \multirow{4}{*}{$\begin{array}{l}\text { Bogen- } \\
\text { lenkung }\end{array}$} & \multicolumn{2}{|c|}{ Kanteneinsatz } & & & & & - & \\
\hline & \multicolumn{2}{|c|}{ Schieben } & & & & & -... & \\
\hline & \multicolumn{2}{|c|}{ Beinedrehen } & & & & & & 0 \\
\hline & \multicolumn{2}{|c|}{ Einseitsfersenschub } & & & & & $\bullet$ & $\bullet$ \\
\hline \multirow{3}{*}{$\begin{array}{l}\text { Pendel- } \\
\text { lenkung }\end{array}$} & \multicolumn{2}{|c|}{ Belastungswechsel } & & & & & - & \\
\hline & \multicolumn{2}{|c|}{ Umkanten } & & & & & 0 & \\
\hline & \multicolumn{2}{|c|}{ Antizipation } & & & & & & \\
\hline \multicolumn{2}{|l|}{ Skistellung } & \multicolumn{7}{|l|}{ Gemisch } \\
\hline \multicolumn{2}{|c|}{ Bewegungsrhythmus } & \multicolumn{7}{|l|}{ Kurz } \\
\hline
\end{tabular}

係，運動のリズムを加え，さらに分かりやすくし たものである．各練習バリエーションことにこの 表を作成することにより，その練習バリエーショ ンがどの構成要素の習得を主目的としているの か，またその前提として習得しておくべき構成要 素は何であるかを明確にすることができる（こ の表を今後「練習バリエーション分類表」と呼ぶ） この練習バリエーション分類表は，技術習得の 際の各構成要素の重み付けを合理的に表すことが できると考えられる，そのことをここでは，プル 一クファーレンとウェーデルンという $2 つ 9$ 技 術に抢ける練習バリエーションを例に取り上げ, その差異を示すことにする。

A. プルークファーレンの練習バリエーショ ン例 (Tabelle 4, 5 参照)

ブルークファーレンの練習バリエーションには 様々なものが考えられるが，ここでは「連続押し
出し」と「大小ブルーク」を例に説明したい，両 者とも主たる目的は，脚の側方への捻り押し出し であるから印の位膡は同じである。しかし，第一 に運動のリズムが異なる. 連続押し出しはリズム が速く, 捻り押し出す動作の感覚が強く意識され るのに対して，大小プルークはリズムが遅くて， 一定の時間その動作を保つため，捻り押し出して いる状態の感覚が強く意識される点に両者の違い がみられる．また，第二に久キーの位固関係では 前者は平行な状態からプルークヘとスキーを捻り 押し出すのに対して，後者は大きなプルークと小 さなプルークを変化させる違いがある。つまり， 同じ構成要素を持った練習バリエーションでも運 動りズムやスキーの位直関係の違いで，それらが 違う目的を持ったものとなり，この練習バリエー ション分類表でその差異を表すことができるので ある。 
Tabelle 9 Klassifikation für Übungsreihe (Wedeln-Drehwedeln)

\begin{tabular}{|c|c|c|c|c|c|c|c|c|}
\hline \multicolumn{2}{|c|}{ Technikkategorie } & \multicolumn{7}{|l|}{ Wedeln } \\
\hline \multicolumn{2}{|l|}{ U̇bungsname } & \multicolumn{7}{|l|}{ Drehwedeln } \\
\hline \multicolumn{3}{|c|}{ Lenkungsfaktoren } & $\begin{array}{l}\text { Aufwärts- } \\
\text { bewegung }\end{array}$ & $\begin{array}{c}\text { Abwärts- } \\
\text { bewegung }\end{array}$ & $\begin{array}{l}\text { Vorwärts- } \\
\text { bewegung }\end{array}$ & $\begin{array}{l}\text { Rückwärts- } \\
\text { bewegung }\end{array}$ & $\begin{array}{l}\text { Seitwärts- } \\
\text { bewegung }\end{array}$ & $\begin{array}{l}\text { Verwindungs- } \\
\text { bewegung }\end{array}$ \\
\hline \multirow{2}{*}{$\begin{array}{l}\text { Belastungs- } \\
\text { lenkung }\end{array}$} & \multicolumn{2}{|c|}{ Mittelbelastung } & $\bullet$ & - & - & $\cdot$ & & \\
\hline & \multicolumn{2}{|c|}{ Außenfußbelastung } & & & & & - & \\
\hline $\begin{array}{l}\text { Entlastungs- } \\
\text { lenkung }\end{array}$ & \multicolumn{2}{|c|}{ Wechselseitentlastung } & & & & & 0 & \\
\hline \multirow{2}{*}{$\begin{array}{l}\text { Haltungs- } \\
\text { lenkung }\end{array}$} & \multicolumn{2}{|c|}{ Mittellage } & $\bullet$ & - & $\bullet$ & - & & \\
\hline & \multicolumn{2}{|c|}{ Gegendrehen } & & & & & & - \\
\hline \multirow{4}{*}{$\begin{array}{l}\text { Bogen- } \\
\text { lenkung }\end{array}$} & \multicolumn{2}{|c|}{ Kanteneinsatz } & & & & & - & \\
\hline & \multicolumn{2}{|l|}{ Schieben } & & & & & $\cdot$ & \\
\hline & \multicolumn{2}{|c|}{ Beinedrehen } & & & & & & 0 \\
\hline & \multicolumn{2}{|c|}{ Einseitsfersenschub } & & & & & - & - \\
\hline \multirow{3}{*}{$\begin{array}{l}\text { Pendel- } \\
\text { lenkung }\end{array}$} & \multicolumn{2}{|c|}{ Belastungswechsel } & & & & & - & \\
\hline & \multicolumn{2}{|c|}{ Umkanten } & & & & & 0 & \\
\hline & \multicolumn{2}{|c|}{ Antizipation } & & & & & & \\
\hline \multicolumn{2}{|l|}{ Skistellung } & \multicolumn{7}{|l|}{ Parallel } \\
\hline \multicolumn{2}{|c|}{ Bewegungsrhythmus } & Kurz & & & & & & \\
\hline
\end{tabular}

B. ウェーデルンの練習バリエーション例 (Tabelle 6-9 参照)

ウェーデルンの練習バリエーションに抢ける分 類表の例である.これらに共通していることは, 抜重操作, 曲進操作と回転操作の構成要素に重み 付けがなされていることである．荷重操作や智 操作は，多くの既習得構成要素をもつことが練習 バリエーション分類表から明らかである．回転操 作に重み付けをおく練習バリエーションとして, Tabelle 6 の「プルークウェーデルン」と Tabelle 7 のステップウェーテルン」を例示す る.この $2 つ の$ 練習バリエーションは, 荷重操 作, 姿势操作, 曲進操作での既習得構成要素は同 じではあるか，抜重操作と回転操作の主目的構成 要素が異なる.すなわち、「プルークウェーデル ン」では荷重交換が，「ステップウェーテルン」 では交互抜重が主目的である，スキ一の位置関係
むプルーク, シェーレと異なる位置関係である. この 2 点から違う綀習バリエーションとして論 理的に分類することができる.

類似した構成要素をむつ練習バリエーション例 としては, Tabelle 8 のベダルウェーデルン」 と Tabelle 9 の「捻りのウェーデルン」が挙げら れる。この2つの練習バリエーションの主目的 構成要素は抜重操作の交互抜重, 曲進操作の脚の 捻りと回転操作の角付け切り替えであり, 既習得 構成要素も同じである．しかし分類項目「C」の 「スキーの位置関係と運動リズム」の例で挙げた ようにスキーの位置関係にプルークが含まれてい るかどうかで分類することができ，捻りのウェー デルンはペダルウェーデルンの練習の発展したも のであることを確認することができる. 


\section{N. 要}

本稿は，運動，操作を項目とするスキー技術の 運動・操作分類法を提案した。この分類法は，入 キ一技術がどのような構成要秦で成り立っている かを明確にでき，体系的にスキ一技術を报うこと を可能とする.このことにより各技術の定義づけ を論理的に行うことが可能になり，さらに構成要 素の概要が明確になることで, 新しい構成要素, さらに新しい技術の発見，開発の可能性む高くな ると思われる．また技術ことの練習バリエーショ ンを整理する手段となることを示した。これらの ことによりスキー指導での練習目的，課題を明確 にすることができ，より段階的，合理的指導を可 能にすると思われる.

我々は，次にバリエーションスキー指導法を報 告する予定である，この指導法は，練習者にとっ て技術を習得するための適切な練習は何かを豊富 な練習バリエーションから目的的に選び出して指 䓕する方法である．各技術ごとの練習バリエーシ ヨンを整理する手段として，運動・操作分類法が 利用できる。

さらに，分類データのデータ構造が 2 次元配 列として扱え，マルチメティアを用いたスキー指 導システム1)などのコンピュータ上で技術や練習 バリエーションを実装するのに有効である.

\section{謝 辞}

この研究の機会を与えて下さった玉川大学橋本 道教授, 古谷太郎教授、玉川学園女子短期大学永 井三千昭教授，お手伝いやアドパイスを頂いた玉 川学園高等部前田二郎教諭, 玉川学園小学部大山 剛教諭、株式会社バークレイ㳇田大介さん，玉川 大学情報通俉工学科卒業生の木澤広君に感謝致し ます。

\section{注}

注1）全体を通してオーストリアスキー用語を多く使 用する。これは日本語，ドイツ語，英唔8)，さらに 混合などによる混乱を少しでむ避けたいからであ る. また近代アルベンスキーがオーストリアにお いて基礎付けられたこと, 日本の教程も当初はオ
ーストリアの影䉕を多大に受けていたこと，その 用語を今現在でもかなり使用していること淿)を考

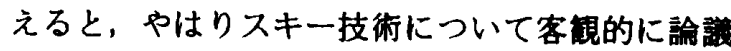
するためには世界の主流であるオーストリアの用 語を使用することが重要だと考えている.

注2） SAJの日本スキー指道教本 ${ }^{26}$ ) は「スキー技術の 内容構造」の「スキーの運動構造と技術内容」の 部分でスキー技術，部分的な技術，技術要秦，そ してスキー操作などと表現をしている。この章で は技術要萦と呼んだその同一の要菜を操作要秦と 呼ぶなど，技術と操作を混同して用いていると思 われる.したがって，その理解が困難である.

注3）ここで練習バリエーションと呼ぶ表現は練習課 題のことである。これは技術と同栐に，それそれ の構成要菜の複合による構成要秉群の集合体であ る.このことから梀習バリエーションは技術と同 様に運動・操作分類法で扱うことができる。

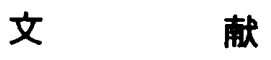

1）安達和年・㴊田大介・国見保夫 - 益田誠也 （1992）スキー学習支挼システムについて。第45 回情報処理学会全国大会論文集 I . : 439-440.

2) Deutscher Verband für das Skilehrwesen (1981) Skilehrplan 1. BLV Verlagsgesellschaft: München, pp. 32-106.

3) Deutscher Verband für das Skilehrwesen (1981) Skilehrplan 2. BLV Verlagsgesellschaft: München, pp. 12-86.

4) G. シュベール：福山和男訳 (1971) 革新フラン ス・スキー、実䍴之日本社 : 東京, pp. 221-240.

5）ショルシュ・シュベール：菱沼信夫訳 (1979) ザ・スキー．実羓之日本社 : 東京, pp. 278-287.

6)福岡孝純（1970）スキー技術の科学的分析, 現 代スキー全集第 3 巻. 現代のスキー技術. 実䍴之 日本社 : 東京, pp. 285-296.

7) Karl Gamma (1992) The Handbook of Skiing. Pelham Books: London, pp. 36-143.

8）岸 正利（1969）用語で賞えるスキー，不昧堂： 東京, pp. 9-130.

9）岸野雄三（1968）序説運動学. 現代保健体育学 大系 9. 大等館書店 : 東京, pp. 83-87.

10）松井三雄（1975）体育心理学（第15版）。体育 の科学社 : 東京, pp. 237-280.

11）中浦こうじ（1991）スキー技術の歴史と系珫. 北海道大学图畫刊行会 : 札璂.

12）中村敏婎（1978）スポーツを考えるシリーズ(3). 大鹪館書店 : 東京, pp. 308-316.

13）中村隆一・斉藤 宏（1992）基礎運動学，医歯 
薬出版会社 : 東京, pp. 267-275.

14）長澤靖夫（1992）スキー指革技術の統合のため の試論.スポーツ運動学研究 3: 15-25.

15）長岡忠一（1989）日本スキー事始め. ペースボ 一ルマカシシン: 東京, pp. 236-284.

16）日本野外教育研究会（1991）スキ一の指尊. 杏 林書院 : 東京, p. 106.

17）大筑立志（1992）たくみの科学. 朝合書店：東 京, pp. 146-148.

18）奥田英二（1986） スキー上達の科学. 講談社： 東京.

19）オーストリア職業スキー教師連盟編 : 杉山進監修 ・児玉栄一訳 (1983) シュビンゲン. 実莱之日本 社 : 東京, pp. 18-21.

20）小原哲郎 (1969）第 2 シー・ハイル（第 7 刷）. 玉川大学出版部：東京, pp. 137-139.

21) Österreichischen Berufsschilehrerverband (1980)
Schwingen. Otto Müller Verlag: Salzburg.

22）佐藤 隆・山川岩之助（1976）学校スキ一の計 画之指党. 第一法規 : 東京, pp. 86-170.

23） SAJ SIA 共同編集委員会·志賀化郎（1991）世 界のスキ一。 山と渓谷社 : 東京, pp. 66-86.

24）高村雄治（1970） スキー指道の科学. 現代スキ 一全集第 3 巻. 現代のスキ一技術. 実業之日本 社 : 東京, pp. 256-284.

25）財団法人全日本スキー連盟編（1986）日本スキ 一教程. スキーシャーナル : 東京, pp. 57-186.

26）財団法人全日本スキー連盟編（1987）日本スキ 一指道教本. スキージャーナル：東京, p. 41.

27）財団法人全日本スキー連盟編（1993）楽しいス キ一教室. スキーシャーナル : 東京, pp. 34-64.

(平成 5 年 10 月 22 日受付 平成 8 年 5 月 18 日受理 